\title{
ISSUES OF CLASS AND CULTURE: AN INTERVIEW WITH AIJAZ AHMAD
}

\author{
conducted by ELLEN MEIKSINS WOOD
}

Question: In your book In Theory: Classes, Nations, Literatures you observe that American literary theory in the last two decades has been remarkably devoid of influences from the major work in Marxist political economy that has been done in the United States, not least by Monthly Review and its publishing house. Why is this significant? Why does literary theory need Marxist political economy?

Ahmad: The latter part of your question can be answered more briefly. Culture is not reducible to those processes that Marxist political economy studies for its own purposes, but culture is embedded in those processes. The so-called "mass culture" today is quite inseparable from processes of mass production, marketing, profiteering, systems of mass communication, etc. Every social practice and all material production involves signification, but neither

In the 1995 summer issue we published a provocative intervicw with the distinguished and controversial Marxist cultural theorist, Aijaz Ahmad, originally conducted by a Slovenian journal, with some modifications for Monthly Review. In that interview, Ahmad answered a wide range of questions on culture and cultural theory, nationalism, the "politics of identity," and the political role of intellectuals. Here we are printing a supplementary interview, conducted by Ellen Meiksins Wood specifically for Monthly Review, which allows Ahmad to pursue some of his ideas in directions that will be of special interest to our readers, dealing with questions about political economy, globalization, class, multiculturalism, and the socialist project of emancipation. 
communication nor fashion nor any other of those things that Cultural Studies takes as its specific object of study is merely or even mainly a signifying practice. Nor can the relation between cultural production and its basis in economic and political processes be read off anecdotally or epiphenominally; it has to be studied rigorously and structurally. You can't just throw in a bit of economics here, a bit of technology there; you have to be able to locate individual facts in a complex historical process, and for that you need very considerable theoretical preparedness. In its beginnings Cultural Studies was quite aware of all this, and some have sought to remain true to those very prosaic origins. In the main, though, Cultural Studies has itself become one of those many styles of consumer capitalism that it sets out to study.

But my reference to Monthly Review that you have recalled meant a great deal more than that. Implied in it was my own sense of the overall structure of the output-in the journal and from the press--that one associates with Monthly Review. It seems to me that in the postwar United States Monthly Review has been the only institution of the Left which provides a full-fledged narrative of the world, for the very period in which this institution has functioned. One doesn't have to agree with all aspects of this narrative, but what I want to emphasize is that there is a narrative of the world more comprehensive than any that has come from any other source in the Anglophone world, and this narrative includes, equally the structures of advanced capitalism as well as the attempts to overthrow it or at least transform it. In scope, this output has been less occupied with Western Europe and Japan, and the latter I think is a special lacuna; but this narrative includes comprehensive histories of people's struggles-specifically revolutionary struggles-a matter that stands in sharp contrast to the output of the New Left Review and its press, the only institution of the Left over the past three decades, albeit outside the United States, that may be compared with Monthly Review either in ambition or in achievement. It is interesting to me that Monthly Review has been relatively less concerned 
with Western Europe, which has been New Left Review'sspecial provenance.

This narrative has some specific features. One is that although it broke with what became of the Soviet state with Stalin and thereafter, it did not become hostile to the myriad Communist movements as such, be they in Cuba, Vietnam, Angola, India, or anywhere else, not to speak of the many revolutionary movements which were not formally communist but were of that kind of inspiration. The criterion of solidarity was not that a movement be Stalinist or Trotskyist or Maoist or Guevarrist or whatever, but that it be revolutionary in a sense that would be recognizably so from a Marxist perspective. I don't mean that I agree with every judgment Monthly Review made based on this principle (its treatment of the Chinese Cultural Revolution is a case in point) but I do greatly support the principle. This remarkable combination of nonsectarianism and profound respect for the revolutionary enterprise gave to the principal tendency of Monthly Review also a remarkable resilience against the two great temptations of our time: social democratic degeneration on the one hand, romance of the national bourgeoisies on the other-and this without devaluing either the importance of whatever reform the working people might be able to win or the importance of anti-imperialist nationalism in the imperialized world. I might add that the editors of Monthly Review have had an exemplary commitment to a certain level of linguistic communication that is necessary for socialist activism. I think that in these times of professionalised jargons on the Left it needs to be said that those "Review of the Month" essays in which Sweezy and Magdoff have over the years given us such lucid analyses of intricate details of high capitalist finance are gems of English prose. That prose should be compulsory reading for Derrideans.

I remember teaching Braverman's great book to undergraduates who had no background in economics and communicating to them something essential, something concrete about what has happened to the American working class in this century. I think a profound sensitivity to work of that kind 
would yield us a very different sense of what gets called "mass culture" in today's Cultural Studies. As I look back on that stream of books that came out of the Monthly Review Press about revolutionary struggles in a host of imperialized countries-Cuba, Vietnam, Guinea-Bissau, Brazil, Colombia, Chile, China, Egypt, and many others-I am firmly convinced that anyone who had seriously attended to the lessons of that documentation could never so easily downgrade the whole question of revolutionary class struggle in favor of "national allegory," "hybridity," "postcoloniality" or whatever else happens to be the fashion of the day. Monthly Review is of course not the only source for knowledge of that kind, but in the United States it has been the largest such source and comparatively the most reliable. So, I find it quite reprehensible that American leftists who want to do radical work in areas of culture and ideology, and who constantly make large statements about the politics of the modern world, especially "Third World," have been so little engaged with the body of theory and information made available by this institution.

Since you have referred to my book I might add that I have of course not written a book in the Monthly Review tradition but some key sections of the book would be better understood in the United States if radicals in that country were better acquainted with this archive in their own national tradition. It interests me that my critics never engage with the two chapters, the introduction and the concluding chapter, which I take to be crucial in the very deliberate design of the book; they only go after the famous names-Said, Jameson, Rushdie-of the middle chapters. Now, the narrative of the postwar world that I provide there is of course not the narrative one would get from Monthly Review, but anyone familiar with the Monthly Review narrative would be well equipped to make sense of the narrative I have assembled in summary. I think that readers who pay little attention to the actual struggles of the people around the world over the past fifty years or more but who know their Benedict Anderson and their Gellner and their Subalternists are very ill-equipped to understand my approach toward nationalism. For example, I view 
the question of nationalism historically. Consequently I may oppose many, many kinds of nationalism, but I also hold on to the importance of anti-imperialist nationalism in a world dominated by imperialism. Similarly, a good number of people can't quite figure out what kind of Marxist I am; they seem to have some very fixed categories in their headStalinist, Trotskyist, Eurocommunist, Maoist, what have youand I don't fit any of those categories. This, then, is made worse by the fact that I write comprehensible prose, which probably means that I couldn't possibly be doing theoretical work; some people have actually declared that I am antitheory. If U.S. radicals knew more about the Monthly Review tradition they would immediately see that I have not written a book in that tradition but they would also have a way of handling some of the things in the book that confuse them.

Q: "Multiculturalism" is a major theme in U.S. intellectual life. Does this strike you as a useful concept? Does it denote a coherent educational or political project?

Ahmad: I believe that the logic of capital is to destroy the integrity of all use values and to impose exchange value upon all productions of value. Which then means that the cultural logic of capitalism is to produce a uniform culture of pure consumption, pure commodity fetishism. I don't mean that the actual, historically constituted cultures of capitalist societies are like that. Capital is never able to resolve the contradictions that it produces. But I do think that the logical tendency of capital is toward subsumption of all cultural value under commodity fetishism. I also speak and write constantly about absolutely necessary tensions between universality and particularity which cannot be resolved. Such tensions can only be lived, and the hope is that they shall be lived not destructively but in a productive relation. But I am under no illusion that this tension can ever be resolved or even need be resolved in any final sense, because both are intrinsic to human social life. With this kind of belief, no one could possibly be against the idea of the multiplicity of cultures or the need to devise educational and political agendas that recognize such multiplicities. 
So one can't be against "multiculturalism" as such. But one can legitimately question, not just from the Right but also authentically from the Left, the way this concept has come into play in the United States. Chronologically, I think, this particular idea of "multiculturalism" has come after and in some covert way against the black insurgency and the women's liberation movement, and of course after the incipient and eventually unrealized anti-imperialist potentials of the antiwar movement. It serves to defuse and even derail the idea that empire and gender and race are central to the structure of differences in U.S. society in a way that differences among, say, the Italian, Jewish, and Polish ethnic groups are not. It denies, in other words, the idea that there is a hierarchy of determination in existing social relations which is an inevitable result of historical formation quite beyond any valuation that any individual may attach to them. It tends to push down in the scale of one's priorities the idea that given the specific history of the United States, given the social structure bequeathed by slavery, the position of African-Americans is uniqueand cannot be collapsed into generalities of ethnicities, difference, and "multiculturalism." In other words, this kind of relativism tends toward the obliteration of actual, historically given relations of power in favor of a levelled out notion of multiplicity and difference in which everyone becomes, sooner or later, everyone else's "other" and, by the same token, a member of a minority and even of a "subaltern" group. Such definitions tend to privilege the idea of culture as signifying system over the idea of culture's embeddedness in material life. They tend to assert discreteness of cultures within a national space, and to privilege ethnicity in the constitution of each culture. A Jewish peddler on New York's Lower East Side then came to have something more fundamentally in common with a Jewish magnate on Wall Street than all the peddlers from different ethnic groups could ever share.

At one end of this ideology, we have the abrogation of any normative sense of cultural value whereby judgments of right and wrong can be made; each culture, as discrete eth- 
nicity, is said to have its own structure of identity formation. At the other end, the ideology of multiculturalism tries to reconstruct, on campuses that have seen intense confrontations on the issue of fatally unequal distributions of power, a celebratory version of U.S. pluralism whereby there is always enough in the basket to go around for everyone and all differences can be accommodated in a non-antagonistic fashion. So in the process of being granted their autonomous spaces, differences are also trivialised. In the actual syllabus formation, this kind of relativism and pluralism typically leads to either a very hardened version of discrete identities, whereby entire courses can be structured around distinct identities, or to sheer randomness in which today's text may illustrate one identity and tomorrow's another, and so on. This kind of multiculturalism in the U.S. college system has had the effect of greatly diluting the original purpose of cultural studies.

Q: In your recent article on the literature of "postcoloniality," you make some provocative suggestions about the current historical conjuncture, arguing that, while there has certainly been an increasing "globalization" of capital, there has, contrary to conventional wisdom, also been "an intensification of the nation-state form." Could you elaborate a bit on this and on the contradictory effects which, you argue, this combination is having on the realms of culture and ideology?

Ahmad: I don't want to repeat what I have said in that article on this issue. So, let me simply give the full reference; it was published in the London-based journal Race and Class, in the January-March issue 1995.

The word "globalization" is, I think, a highly ideological word, and as such actually refers to quite a few different things. At one level, it simply means that with the collapse of the Soviet Union and the system of the states it represented there is now only one system, that of imperialist capital, and everyone better accept this fact. Those who celebrate "globalization" don't put it so brutally, but that's what they mean. Second, the term refers to tremendous mobility of capital and com- 
modities, the increased role of export/import trade in national accounts, the power of communication and transport technologies with unparalleled global reach, the enormous power of finance capital and speculation over and above industrial capital across national frontiers, the ability of new and centrally-produced cultural commodities to bypass national apparatuses of education and information through telecasting and information highways, the rise of production and management systems in which the production process itself can be fragmented and located in different countries and/or quickly moved from one to the other, and so on. Third, the term "globalisation" is also a euphemism for the fact that a handful of imperialist institutional arrangements-the World Bank, IMF, GATT etc.-are now determining national policies across the so-called Third World. Fourth, it refers to the rapid penetration of all production by capitalism, hence by the world market. The World Bank calculated that by the end of the century only twelve per cent of the economic production in the world will be outside the global capitalist market as such.

At the macro-economic level, there are powerful tendencies and I do not wish to understate their importance. In some ways none of this is very surprising. Capital has had a tendency toward transnationalisation since its very inception, as not only Marx but also Luxemberg and Lenin knew very well. This is part of the story of colonialism, for example. Lenin's definition of imperialism would mean nothing without this historical tendency. What I am saying is something else. The first point is that there is another, equally powerful historical tendency, the one toward a far greater mobility of capital and relative immobility of labor, which still holds. One feature of this other tendency is that while capital seeks to travel across national frontiers, regimes of labor still continue to be national regimes. There is a pretence in most kinds of economics that prices are determined-perhaps brutally but "freely"-in the market. This simply is not so. Prices, especially the prices of labor, are determined historically, and 
the nationally constituted disciplines and regimes of labor are a fundamental component to that history.

Even in the most advanced capitalist countries, the nation-state is alive and well. Japanese capital is both transnational and aggressively Japanese. Germany has achieved its expanded national unification only recently, and one would have to be a fool not to see that there is a relationship between the German national in terest and the Bundesbank. I also read somewhere that something like 95 percent of U.S. savings are invested inside the country. I might add that mutual accommodation of national interests is much more possible among the most advanced capitalist countries and one may speak with relatively greater justice of a market of "free" exchanges among them. But as soon as you look at the "globalization" that connects the imperialist countries with the imperialized ones, you become much more aware of national differentiations and coercions.

Which brings me to the question of colonialism and the so-called "postcolonialism." I mean, first of all, the hard materialities of it. How does U.S. capital arrive in Bangalore today, in the context of a sovereign Indian state, to exploit the cheaper labor and industrial plant there, including even intellectual labor? Is there a colonial empire to make free entry possible, as it was possible for British capital to come to India during the Raj? Or is there just an open global market for capital to travel on its own volition? Not at all. That capital must pass through the Indian nation-state, must rely on certain disciplines of labor, wage contracts, conditions of industrial peace, chances of repatriation of profits that only the Indian state can guarantee. The nation-state in this case is the articulating principle between global capital and national labor.

From whose point of view do you then read history? From the standpoint of capital that circulates globally, or from that of labor which is everywhere in chains? I think the metropolitan intellectuals who are such enthusiasts of globalization should organize a movement for the abolition of passports, so that we may actually have movements of labor 
almost as free as the movements of capital itself. Let all the U.S. capital come to India and all the Indian workers go to the U.S. to earn U.S. wages. Let there be a global equalization of wages and profits. Here I am not asking for socialism, only that the bourgeoisie be true to its word: free movements of people. The struggle for socialism shall be I think easier in a world turned so upside down.

What does it mean for "realms of culture and ideology?" It depends on what sites of cultural and ideological production you have in mind. I think that the intellectuals in the metropolitan countries who speak of a "world culture," without foregrounding the fact that a "world culture" in this circumstance can only be the predominance of imperialist culture, are paving a way to hell with good intentions. As I look at this process from inside India, what I find is a powerful affirmation of the good old Marxist idea that economics and culture go hand in hand. In fact, the contemporary evidence is that one experiences the shifts in the realm of culture even before those shifts take hold fully in the economic realm. The Indian government, politically bankrupt to its core, has now had the policy of "globalization" and "liberalization" in the current sense for barely five years or so. During this time, very little Western investment capital has actually come in because they want even more favorable conditions. But the flooding of India with western cultural artifacts, from entertainment grids to consumption goods to ideologies of consumption, has been much more far-reaching.

In these circumstances, one is struck by two parallel developments in the ideological realm of what gets called "cultural studies." There is the idea of the discreteness of identities, cultural, ethnic, or national; a kind of remorseless differentialism, whereby I am not permitted the claim that I may understand your identity but I am supposed to simply respect whatever you say are the requirements of your identity. In this ideology, any number of people celebrate hardened boundaries between self and other, denounce what they understand as the "universalism" of the Enlightenment, rationalism, and so on, while also fully participating in the 
globalization of consumption patterns and the packaging of identities as so many exhibits. At the same time and often from the same people, we also have the propagation of the idea of infinite hybridity, migrancy, choice of alternate or multiple identities, as if new selves could be fashioned in the instant out of any clay that one could lay one's hands on, and as if cultures had no real historical density and identities could be simply made up, sui generis, out of the global traffic and malleability of elements taken from all over the world.

Q: In the same article, you remark that "postcoloniality is also like most things a matter of class." This kind of emphasis on class is, of course, deeply unfashionable. Without dwelling on the notion of "postcoloniality" (if it isn't too frivolous to ask for an answer in such a limited space), would you care to justify the sweeping proposition that "most things" are a matter of class?

Ahmad: Let me first make explicit a rather memorable reference there. In her biography of Chu Teh, the great commander of the People's Army during the Revolution in China, Agnes Smedley recalls a moment when she had asked him about his having been a bandit and a thief in his youth. As Smedley tells it, Chu Teh fell silent for a while and then said something like, "Theft, you know, is also a matter of class." I read that book when I was a very young boy but the truth of that simple statement has stayed with me all these years, and in paraphrasing those words I just wanted to record my admiration for both Smedley and Chu Teh.

But you have asked me to justify those words. I'm not sure how one justifies words so obviously true. India is said to have a population between 900 and 1,000 million. Roughly half of them are illiterate; but no bourgeois is illiterate anywhere in the world and those who constantly speak of "the pleasure of the text" are never poor. Roughly half of the world's blind people live in India; but blindness too is a matter of class, in the sense that blindness is overwhelmingly a disease of the poor and in the sense that such high incidence of blindness has a lot to do with living in conditions that produce blindness, with number and quality of hospitals, with the 
ability to pay for cure and care. What needs to justify itself is that other kind of blindness, which refuses to see that most things are a matter of class. That refusal is itself very intimately a matter of class.

The real question, then, is: why does one need to reiterate a truth so obvious? I think that the institutionalizing of certain kinds of radicalism has gone hand in hand with a certain sanitization of vocabulary, which is ultimately quite devastating for thought itself. One begins with the idea that there is some economic determination in social life but also that, as Althusser famously put it, "the lonely hour" of that final determination "never comes." In the next step, one forgoes the idea of economic determination altogether. Then, the critique of capitalism is sundered from any forthright affirmation of what might replace it. So, the more anti-bourgeois, and anti-colonial etc. one becomes, the less one talks about socialism as a determinate horizon. In the process, critiques of capitalism are also sundered from any necessity of working class politics. Indeed, one may use the word "bourgeois," in a cultural sort of sense, but the word "proletariat" makes one distinctly uncomfortable, as if using such words is some kind of anti-social activity. One may speak of any number of disorientations and even oppressions but one cultivates all kinds of politeness and indirection about the structure of capitalist class relations in which those oppressions are embedded. To speak of any of that directly and simply is to be "vulgar." In this climate of Aesopian languages it is absolutely essential to reiterate that most things are a matter of class. That kind of statement is I think surprising only in a culture like that of the North American university in which radicalism has not had a powerful connection with movements of the working class in a long time. But it is precisely in that kind of culture that people need to hear such obvious truths.

Q: You have made some very trenchant criticisms of contemporary literary and cultural writings by thinkers who are very influential on the intellectual left. These criticisms have generated a great deal of controversy. What aspects of 
your criticisms seem to have been most difficult for people to accept? Why? Have you been surprised by the reaction? Have people been missing the point? What do you regard as most important of your criticisms? Do you want to set the record straight in any way?

Ahmad: I can say quite truthfully-I don't mean I am necessarily right, but I do think-that no real controversy on my book has ever taken place. I said earlier that so far as I am concerned, the burden of the main argument is contained in the Introduction and the last chapter. To my knowledge, no one has engaged with those in print. The chapter that has had the most electrifying effect in literary circles in India, the one on Indian literature, has never been discussed in the West; most people who have commented on my book there simply don't know what I'm talking about. Most critics latch on to the three middle chapters, about individuals and largely about individual texts, but in ways that I find bewildering. I have said that Jameson is to my mind the most important living literary theorist in the English language today, from whom I have learned a great deal but I am writing critically about him because I reject the idea that every text from the Third World is to be read as a "national allegory" and the further idea that nationalism is the determinate answer to what Jameson calls "American postmodern culture." This very high praise for Jameson-(Is he really that much better than Eagleton?)-I am not inventing now, "to set the record straight"; it is there in the very essay I wrote in response to his essay. No one has yet refuted what I have actually said about "national allegory," etc; but it is alleged that what I have said amounts to "attack," "vilification," and so on- without any citation of any discourteous phrase I might have used about Jameson. The same sort of thing has happened about my criticism of Rushdie. I have been calling Khomeini a "clerical fascist" since the day he took power- when some of the more notable defenders of Rushdie were being very enthusiastic about the so-called revolutionary tradition of the Irani clergy and were concentrating only on the misrepresentation of Islam in the U.S. mediayou only have to look at Edward Said's Covering Islam and the 
issue of Race and Class which covered the Irani Revolution at that time to see what I mean. But I am accused of waging a jihad against Rushdie, as someone has written in the prestigious U.S. journal, Public Culture.

So the matter boils down to the chapter on Edward Said. The last one-third of that chapter is a close scrutiny of two of Said's essays; I have never come across a single critic or reviewer who has engaged with that part of the chapter. Even about Orientalism, I think that the so-called "controversy" has never actually dealt with the main issues: Said's insistence on a remorseless continuity from Greek tragedy onwards; his uncertainty and even error in specifying the relationship between imperialism and the Eurocentric biases in modern European discourses about non-Europe; his privileging of written textuality in general and of literature in particular in this narrative of Europe's domination over non-European; his neglect of the fact that much more than the Arab East, it is India, China, and generally the far East that have been far more central in the system of knowledges that we can properly call "Orientalism"; his careless remarks about such key figures as Dante and Marx; his astonishing levelling of all kinds of European knowledges under the singular heading of Orientalism, whereas, for example, anyone who knows anything about India would find it scandalous that both William Jones and Macauley are so easily called "Orientalist," and so on. All kinds of historical specificities are sacrificed for the making of this construct called "Orientalism." I have never denied that in the Eurocentric atmosphere prevailing in the U.S. academy Orientalism has had quite considerable salutary effects, especially in areas of literary study and Middle Eastern Studies. I did not dwell on those positive aspects because they are well known. I thought, instead, that one should address some other aspects of that work which have indeed done very considerable harm. I must say that the substance of my argument, which I have illustrated here in the form of separate questions, was never answered. Looking back, I now think that there certainly were places where I mishandled the rhetoric, but it also interests me that verbal exaggerations of a negative 
kind were made the issue but the same people never mentioned that I had praised Said in the highest terms for his personal courage and the work he has done on the issue of Palestine. So the reading of the rhetoric was itself tendentious. If you discount short reviews, Michael Sprinker is the only one among the critics who have written at any length about my book who has in fact addressed any of the issues that were central to its argument.

Was I surprised? Very much. By the attention that the book got, and then even more by the will of the detractors to personalize the whole issue, as if the book were nothing more than a "vilification" of a couple of individuals. It has been very discouraging for me that people who write about the book normally don't engage with the more substantive chapters: the Introduction, the last chapter, what I have to say about Marx or India or about Indian Literature, most of the basic issues I raise about the authors whose fame preoccupies those who usually feel constrained to write about my book. My chapter on Shame opens with a discussion of the connection there might be between the way the issue of "migrancy" gets posed in Rushdie's kind of fiction, the circulation of multinational capital, and of the personnel thrown to the whirlwind by that circulation, in our time-between the cultural "hybridity" that is celebrated these days, the fragmented and polyglot surface of literary texts made familiar to us by such masterpieces of modernism as The Waste Land, and the patterns of consumption symbolized by the supermarket in an age of globalized circulation of commodities. It has been both a surprise and a regret for me that the kind of "cultural studies" we now have just doesn't engage with questions of that kind, not when it comes to a serious discussion of a novel written by somebody who now commands an iconic status in the West thanks to his conflict with "Islamic fundamentalism." I find this kind of self-righteousness very amusing, considering that my own tussle with Islamism started much earlier.

Q: Some kinds of "relativism"-cultural, even moralused to seem progressive, in the sense that they resisted various claims to moral or cultural superiority which could be 
used to justify domination, oppression, imperialism, and so on. Today, the socialist left often finds itself defending "universalist" principles against new forms of particularism and relativism; and you, for example, have had some very strong things to say about poststructuralist and postmodernist particularisms, "identity" politics, extreme forms of "cultural differentialism," and so on. Can you offer any simple rules for negotiating the difficult transactions between "universalism" and "particularism?" Is there a way of granting recognition to human "difference" without giving up the kinds of universal principles that used to underlie the socialist project of a general human emancipation?

Ahmad: Let me first tell you something about my $e x-$ perience before going on to history and theory. I was born and bred in a society with a phenomenal range of diversities of all kinds. The Anthropological Survey of India tells us that there are today some three thousand distinct communities in India, something like 360 languages and dialects. It might also interest you that according to the same Survey sixty or so percent of the Indian people think of themselves as migrants, as having come from elsewhere in the country. Historians of Early Medieval India tell us that the people who do notbelieve in any grand religions--Hinduism, Islam, Christianity, etc.have always been the majority in this country. Meanwhile, a sense of a sub-continental entity also begins early. I think it has something to do with geography, with being bounded by very tall mountains on one side and a vast ocean on the other, and with the massiveness of alluvial plains and the riverine systems. This sense of an entity is there even in the territorial expanse over which the stories of the Mahabharatha unfold. Some of it gets embedded in the Early and Medieval imperial consolidations. By the time of the devotional theisms of the medieval times a certain sensibility can be found among the popular classes across India, grounded in regional idioms but profoundly humanist and universalist. In the more recent centuries, the generalization of capitalist market, the national anti-colonial movements and then, since Independence, a system of representative government based on universal 
franchise, not to speak of modern travel, communication etc., has also produced a profound sense of a modern polity and a territorial nation.

In a nation so very heterogeneous, negotiations between universality and particularity, between migrancy and a sense of place, is daily experience; even the Constitution of India has to recognize twenty national languages against one in the United States or two in Canada. One has a profound sense of belonging to all of it yet the knowledge that one would not understand even a fraction of it, even in the simple sense of exchanging mutually intelligible words. So, when these same issues surface in such facile ways in the exhortations of "identity politics," as if these were grand discoveries of the postmodern, I don't quite understand-I understand cerebrally but I don't understand in the gut-what the fuss is all about.

I don't mean that everyone in India lives like that. All sorts of abominable things happen. I meant to say something about my own experience and the experience I share with other progressive people like myself, and there are millions of us, I don't know how many but a great many-and about the very textures of daily life that people share without having actually theorized about it. And what I meant to say was that in this life, and in the lives of countless people, generation after generation, there have been so many ways, traditional ways and modern ways, of reconciling "universalism" and "particularism" that there have been for me many quite concrete ways of negotiating my own experience. These ways are quite different from the way this question gets posed in societies like those of North America which have very brief histories and which carry such burdens of racial genocide, slavery and migration-societies that have relatively little that is older than a capitalist ethic and not much of a communist tradition.

In more impersonal terms of history and theory, I would again bring up the issue of rights, about which I write and speak constantly because I think it is important to come at it from different angles. I think that there is a terrible distortion in 
the way the history of "universalism" gets recounted in the polemics against the Enlightenment, post-Enlightenment etc. In such accounts, the discourse of rights remains where it began, namely in the proposition that the locus of all rights is the individual, that this individual has no attributes other than that of citizenship, that the structure of universal rights must follow the logic of universal laissez-faire which itself emanates from the pre-Ricardian notions of the so-called free market. I don't think that the debate has been frozen at that point of origin for all these years. Rather, there have been constant struggles. In our own time, a whole range of theories-Marxist certainly but even liberal-feminist, secular, anti-colonial and anti-racist theories, not to speak of the extremely complicated discourses of minority rights-which have amply demonstrated that the supposedly attribute-less individual that laissez-faire liberalism proposes is, under the ideological surface, none other than the white bourgeois male. And that even liberal theory must face up to the fact that the individual who might be not-male, not-white, not-bourgeois cannot be called upon to surrender her attributes to an abstract universality.

The whole issue of the commensurability of universal rights with rights of various kinds of minorities is at least as old as Locke. Historically, the capitalist state has of course not granted to workers or women the rights that should be theirs but an idea is commonly held that there are rights that are specific to workers as workers and to women as women. There is an idea of the right of historical redress, in the form of affirmative actions, for sections of the population whose present disadvantage is rooted in the accumulated oppressions of the past. In the advanced capitalist countries, the state is in the process of being pushed to accommodate itself to the rights of the elderly, the physically handicapped. Everywhere in the world, the illiberal as well as the liberal are being called upon to accommodate themselves to the rights that are specific to what remains of those indigenous peoples whose lives are constantly shattered by capitalism's conquest of $\mathrm{Na}$ ture. A recognition is beginning to dawn upon political theory 
that situations of individuals and communities are so various that the secondary structure of particular rights will cumulatively far surpass the underlying structure of universal rights. Neither the beginning of trade union rights in the nineteenth century nor the expanding structure of women's rights in the twentieth; neither the civil rights legislation in the United States nor the ideology of the welfare state in Western Europe, would be conceivable outside the extremely difficult problematic of reconciling, on the terrain of practical social covenants, the universal and the particular.

None of it has given us anything resembling what I might mean by socialism but there have been people's struggles and those struggles have sought a simultaneity of both universal and particular rights. I think we do a great disservice to the memory of those struggles when we speak only of what they failed to achieve and not of what they did achieve. And we do a great disservice to ourselves because that isour own history. The common people, the people who fought for a decent life, always said, let's all have equal rights but let's also take care of those who have special needs. They didn't have fancy language but they knew what we, as intellectuals, mean by "universal" and "particular."

What I am trying to say, I think, is that we certainly need the most rigorous of theories but we also need to have memories of the traditions of mercy and the struggles for justice. It is only there that any true reconciliation of the universal and particular is really possible.

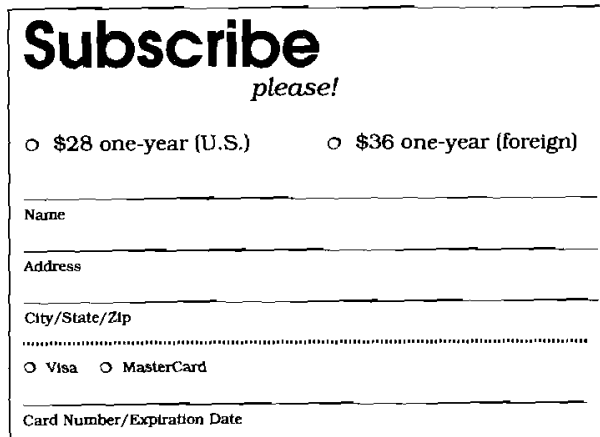

MONTHLY REVIEW

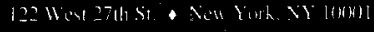

